\title{
SISTEM PEMBINAAN PARA NARAPIDANA UNTUK PENCEGAHAN RESIDIVISME
}

\author{
Oleh \\ Rommy Pratama*)
}

\section{Abstrak}

Lembaga pemasyarakatan merupakan tempat untuk melaksanakan pengayoman serta pemasyarakatan narapidana, akan tetapi di sisi lain Lembaga Pemasyarakatan memang tidak bisa memberikan suatu jaminan, bahwa warga binaan yang sudah dibina itu pasti mau mentaati peraturan dan tidak melakukan kejahatan lagi, serta juga tidak ada jaminan bahwa program yang dilaksanakan dalam rangka pengayoman serta pemasyarakatan warga binaan pasti membawa hasil yang memuaskan. Pembinaan yang diberikan kepada narapidana yang berorientasi pada masa depan yang cerah dapat diwujudkan, apabila narapidana itu secara sungguh-sungguh menyadari bahwa pidana penjara yang dijatuhkan kepada mereka bukanlah dimaksudkan untuk membalas perbuatan yang dilakukan oleh warga binaan itu, akan tetapi untuk mengayomi serta memasyarakatkan napi itu kejalan yang benar agar mereka menjadi manusia yang baik dan bertanggung jawab sesuai dengan harkat dan martabatnya.

\section{Kata Kunci : Narapidana, Residivisme}

\section{A.PENDAHULUAN}

Negara Republik Indonesia adalah Ne-gara yang berdasarkan atas hukum, ketentuan ini tercantum dalam penjelasan UUD 1945 yang secara tegas menyatakan bahwa "Negara Indonesia berdasarkan atas hukum (rechtstaat) tidak berdasarkan atas kekuasaan belaka (machstaat)". Dalam Pembukaan UUD 1945 diamanatkan kepada bangsa Indonesia untuk melindungi segenap bangsa Indonesia dan seluruh tumpah darah Indonesia dan untuk memajukan kesejahteraan umum, mencerdaskan kehidupan bangsa, dan ikut melaksanakan kertertiban dunia yang berdasarkan kemerdekaan, perdamaian abadi, dan keadilan sosial.

Hukum yang diciptakan oleh manusia mempunyai tujuan untuk men-

*) Penulis adalah Dosen Fakultas Hukum Universitas Islam Syekh Yusuf Tangerang ciptakan keadaan yang teratur, aman, dan tertib, demikian juga hukum pidana yang merupakan salah satu hukum yang dibuat oleh manusia mempunyai dua fungsi yaitu:

1. Fungsi umum dari hukum pidana sama dengan fungsi hukum lainnya ialah mengatur hidup kemasyarakatan dan menyelenggarakan tata hidup didalam masyarakat.

2. Fungsi khusus bagi hukum pidana ialah melindungi kepentingan hukum terhadap perbuatan yang hendak memperkosanya dengan sanksi berupa pidana.

Pidana penjara itu adalah suatu pidana berupa pembatasan kebebasan bergerak dari seorang terpidana yang dilakukan dengan menutup orang tersebut di dalam sebuah Lembaga 
Pemasyarakatan, dengan mewajibkan orang untuk mentaati semua peraturan dari tata tertib yang berlaku di dalam Lembaga Pemasyarakatan yang dikaitkan dengan sesuatu tindakan tata tertib bagi mereka yang telah melanggar peraturan tersebut.

Secara yuridis formal, masalah pemberian sanksi pidana di Indonesia dikenal sejak berlakunya Kitab Undang-Undang Hukum Pidana (KUHP). Dalam KUHP itu terdapat ketentuan pasal mengenai sanksi pidana yaitu Pasal 10 KUHP, yang berbunyi bahwa Pidana terdiri atas:

a. Pidana pokok :

1. Pidana mati

2. pidana penjara,

3. kurungan,

4. denda,

5. pidana tutupan (UU N. 20 Tahun 1946

b. Pidana tambahan:

1. pencabutan hak-hak tertentu,

2. perampasan barang tertentu,

3. pengumuman putusan hakim.

Narapidana adalah manusia yang memiliki spesifikasi tertentu, secara umum Narapidana adalah manusia biasa seperti kita semua, namun kita tidak dapat begitu saja menyamakan begitu saja. Dalam konsep pemasyarakatan baru Narapidana bukan saja sebagai obyek melainkan juga sebagai sebagai subyek yang tidak berbeda dengan manusia lainnya yang sewaktuwaktu dapat melakukan kesalahan atau kekhilafan yang dapat dikenai pidana, sehingga tidak harus diberantas. Bagaimanapun juga Narapidana adalah manusia yang memiliki potensi yang dapat dikembangkan untuk menjadi lebih produktif, untuk menjadi lebih baik dari sebelum menjadi pidana. Sistem pemasyarakatan erat kaitannya dengan pelaksanaan pidana hilang kemerdekaan yang dilatarbelakangi oleh maksud dan tujuan penjatuhan pidana. Pelaksanaan sistem hilang kemerdekaan yang berlangsung selama kurun waktu tertentu telah merupakan refleksi historis dalam perkembangan falsafah Peno koreksional dari masa ke masa. Secara singkat dapat di katakan sejarah Pemasyarakatan memuat value oriented atau value centered, karena sistem pemasyarakatan itu sendiri dengan konsisten dengan sistem nilai yang berlaku di masyarakat.

Konsepsi pemasyarakatan ini, bukan semata-mata merumuskan tujuan dari penjara, melainkan suatu sistem pembinaan, suatu metodologi dalam bidang "treathment of offenders".

Sistem Pemsyarakatan bersifat multilateral oriented, dengan pendekatan yang berpusat kepada potensipotensi yang ada, baik pada individu yang bersangkutan maupun yang ada di tengah masyarakat, sebagai suatu keseluruhan. Secara singkat, sistem pemasyarakatan adalah konsekuensi adanya pidan penjara yang merupakan bagian dari pidana pokok dalam sistem pidana hilang kemerdekaan.

Istilah "Pemasyarakatan" secara resmi menggantikan istilah kepenjaraan sejak tanggal 27 April 1964 melalui amanat tertulis Presiden Soekarno dibacakan pada konferensi Dinas Para Pejabat Kepenjaraan di Lembang Bandung. Amanat ini dimaksudkan dalam rangka "retooling" dan "reshaping" dari sistem kepenjaraan yang dianggap tidak selaras dengan adanya ide Pengayoman sebagai konsepsi hukum nasional yang berkepribadian Pancasila. Selanjutnya ide Pemasyarakatan dicetuskan oleh Dr. Saharjo, SH tepatnya pada tanggal 5 Juli 1963 dalam pidato penganugerahan gelar Doctor Honoris Causa di bidang ilmu hukum oleh Universitas Indonesia.

B. PEMBAHASAN 
Ketika berbicara tentang kejahatan, maka seringnya yang pertama muncul dalam benak kita adalah pelaku kejahatan. Kita biasa menyebut mereka penjahat, kriminal, atau lebih buruk lagi, sampah masyarakat, dan masih banyak lagi. Masyarakat sudah terbiasa, atau dibiasakan, memandang pelaku sebagai satu-satunya faktor dalam gejala kejahatan. Maka tidaklah mengherankan bila upaya penanganan kejahatan masih terfokus hanya pada tindakan penghukuman terhadap pelaku. Memberikan hukuman kepada pelaku masih dianggap sebagai "obat manjur" untuk "menyembuhkan" baik luka atau derita korban maupun kelainan perilaku yang "di idap" pelaku kejahatan.

Herbert L. Packer dalam bukunya 'The Umits of The Criminal Sanction' menyebutkan bahwa sanksi pidana suatu ketika merupakan penjamin yang utama atau terbaik dan suatu ketika merupakan pengancam yang utama dari kebebasan manusia itu sendiri. Sanksi pidana merupakan penjamin apabila dipergunakan secara hemat, cermat, dan manusiawi. Sementara sebaliknya, bisa merupakan ancaman jika digunakan secara sembarangan dan secara paksa. Faktanya, banyak ditemukan kekerasan dan penyalahgunaan kekuasaan yang menyebabkan viktimisasi terhadap para terpidana. Konsep Lembaga Pemasyarakatan pada level empirisnya, sesungguhnya, tak ada bedanya dengan penjara. Bahkan ada tudingan bahwa Lembaga Pemasyarakatan adalah sekolah kejahatan. Sebab orang justru menjadi lebih jahat setelah menjalani hukuman penjara di Lembaga Pemasyarakatan. Ini menjadi salah satu faktor dominan munculnya seseorang bekas narapidana melakukan kejahatan lagi, yang biasa disebut dengan residivis.
Pengintegrasian kembali narapidana ke dalam masyarakat harus dilakukan lewat tahapan self realisation process. Yaitu satu proses yang memperhatikan dengan seksama pengalaman, nilai-nilai, pengharapan dan citacita narapidana, termasuk di dalamnya latar belakang budayanya, kelembagaannya dan kondisi masyarakat dari mana ia berasal.

Penjara yang telah melakukan segala usaha untuk merabilitasi penjahat tidaklah lebih berhasil dari pada penjara yang membiarkan penghuninya "melapuk" dan bahwa rehabilitasi adalah kebohongan yang diagung-agungkan. Kita melihat kenyataan yang sebenarnya bahwa penjara mengasingkan penjahat dari cara hidup yang wajar sehingga la tidak siap untuk hidup di jalan yang benar setelah ia dibebaskan dari penjara. Juga kenyataan adanya kekerasan dalam penjara yang merendahkan martabat manusia di penjara. Yang dimaksud di sini adalah, penjara telah mengasingkan penjahat dari cara hidup yang wajar melalui sikap para petugas penjara terhadap para terpidana yang selalu diiringi rasa was-was, mereka merasa setiap saat dalam keadaan bahaya karena mereka dikelilingi oleh penjahat yang dicurigai setiap saat memberontak.

Selain itu jenis keterampilan atau pekerjaan yang ada sangat terbatas dengan upah yang tidak memadai. Ironisnya, hampir seluruh tindak kejahatan yang ditangani oleh Sistem Peradilan Pidana Indonesia selalu berakhir di penjara. Padahal penjara bukan solusi terbaik dalam menyelesaikan masalah-masalah kejahatan, khususnya tindak kejahatan di mana "kerusakan" yang ditimbulkan oleh tindak kejahatan tersebut masih bisa di restorasi sehingga kondisi yang telah "rusak" dapat dikembalikan ke keada- 
an semula, di mana dalam keadilan restoratif ini dimungkinkan adanya penghilangan stigma dari individu pelaku. Dalam menyikapi tindak kejahatan yang dianggap dapat di restorasi kembali, dikenal suatu paradigma penghukuman yang disebut sebagai restorative justice, di mana pelaku di dorong untuk memperbaiki kerugian yang telah ditimbulkannya kepada korban, keluarganya dan juga masyatakat.

Berkaitan dengan kejahatan yang kerusakan masih bisa diperbaiki, pada dasarnya masyarakat menginginkan agar bagi pelaku diberikan "pelayanan" yang bersifat rehabilitatif. Masyarakat mengharapkan para pelaku kejahatan akan menjadi lebih baik dibanding sebelum mereka masuk kedalam institusi penjara, Situasi program pembinaan keterampilan kerja/latihan kerja yang sekarang ini berjalan di dalam dan luar lembaga, Dengan mencari hasil signifikansi program tersebut untuk menjadi faktor penghalang seorang mantan penghuni penjara kembali ke dalam penjara. Dan akan dianalisa seberapa besar signifikansi program pembinaan tersebut telah sesuai dengan nilai-nilai restorative justice system.

Dengan munculnya peace making criminology yang menawarkan suatu pilihan tentang bentuk penghukuman yang bersifat non-violence dilakukan di luar lembaga pemasyarakatan, melibatkan partisipasi aktif korban, bersatu untuk mengintegrasikan pelaku ke dalam masyarakat, melalui suatu mekanisme mediasi, yang kemudian dikenal dengan restorative justice. Restorative justice adalah suatu proses dimana semua pihak yang terlibat dalam suatu tindak pidana tertentu bersama-sama memecahkan masalah bagaimana menangani akibatnya di masa yang akan datang. Dilihat dengan kaca mata restorative justice, tindak pidana adalah suatu pelanggaran terhadap manusia dan relasi antar manusia. Tindak pidana menciptakan suatu kewajiban untuk membuat segala sesuatunya menjadi lebih baik dengan melibatkan korban, pelaku, dan masyarakat dalam mencari solusi untuk memperbaiki, rekonsiliasi, dan menentramkan hati.

Korban, dalam pandangan restorative justice, adalah orang yang menjadi target atau sasaran kejahatan, anggota keluarganya, saksi mata, anggota keluarga pelaku, dan masyarakat secara umum. Tindak pidana memunculkan kewajiban dan liabilitas. Pelaku harus dibantu untuk sadar akan kerugian atau kerusakan yang timbul dan dibantu dalam menunaikan kewajibannya untuk secara maksimal memulihkan kerugian atau kerusakan yang timbul sebagai akibat dari perbuatannya. Kesadaran yang muncul, keinginan untuk memulihkan, dan pelaksanaan pemulihan kerugian atau kerusakan diharapkan muncul karena kerelaan dari pelaku tindak pidana bukan dikarenakan adanya paksaan dari pihak lain, Di sisi lain, masyarakat juga mempunyai kewajiban terhadap korban dan pelaku tindak pidana dalam mengmtegrasikan mereka kembali ke dalam masyarakat dan menjamin terbukaluasnya kesempatan bagi pelaku untuk dapat memperbaiki din dan kembali aktif di dalam masyarakat. Kebutuhan dan keselamatan korban menjadi perhatian yang utama dari proses restorative justice. Korban harus didukung dan dapat dilibatkan secara langsung dalam proses penentuan kebutuhan dan hasil akhir dari kasus tindak pidana yang dialaminya. Namun dengan demikian bukan berarti kebutuhan pelaku tindak pidana diabaikan. Pelaku tindak pidana harus direhabilitasi dan direintegrasikan ke dalam masyarakat. Konsekuensi dari kondisi 
ini mengakibatkan perlunya dilakukan pertukaran informasi antara korban dan pelaku tindak pidana secara langsung dan terjadinya kesepakatan yang saling menguntungkan di antara keduanya sebagai hasil akhir dari tindak pidana yang terjadi.

Proses restorative justice merupakan proses keadilan yang sepenuhnya dijalankan dan dicapai oleh masyarakat. Proses yang benar-benar harus sensitif terhadap kebutuhan masyarakat dan benar-benar ditujukan untuk mencegah dilakukannya kembali tindak pidana. Hal ini menjadikan keadilan sebagai sesuatu yang penuh dengan pertimbangan dalam merespon kejahatan dan menghindari terjadinya stigmatisasi. Sehingga sangat disadari perlu dijalankannya suatu mekamsme monitoring di dalam masyarakat terhadap pelaksanaan hasil akhir dari penyelesaian suatu tindak pidana, menyediakan dukungan, dan dibukanya kesempatan yang luas bagi stakeholder kunci. Hasil analisa terhadap existing legal framework dan dikaitan dengan perspektif restorative justice adalah:

- Konsep Sistem Pemasyarakatan dalam instrumen nasional tentang reaksi negara terhadap orang yang telah divonis melanggar hukum, yang diilhami oleh 10 Prinsip Pemasyarakatan dari Dr. Sahardjo, memperlihatkan kecenderungan nilai dan pendekatan yang hampir sama dengan nilai dan pendekatan yang terdapat dalam instrumen internasional tentang perlakuan terhadap tahanan dan narapidana, sebagaimana termuat dalam Peraturan-peraturan Standar Minimum (Perserikatan Bangsa Bangsa) bagi Perlakuan terhadap Narapidana, resolusi 663 C (XXIV)/1957 dan resolusi 2076/1977. Meskipun dalam undang-undang tentang peng- hukuman dalam sistem peradilan Indonesia tidak diatur secara detail perihal perlakuan minimal yang diberikan oleh negara. Baik Konsep Sistem Pemasyarakatan maupun Peraturan-peraturan Standar Minimum Bagi Perlakuan terhadap Narapidana menganut filosofi penghukuman yang diwarnai pendekatan rehabilitatif, yaitu pendekatan yang menganggap pelaku pelanggar hukum sebagai pesakitan dan karenanya harus disembuhkan.

- Hak-hak narapidana atau orangorang yang dipenjara sebagaimana tercantum dalam Peraturan-peraturan Standar Minimum (Perserikatan Bangsa Bangsa) bagi Perlakuan terhadap Narapidana, resolusi $663 \mathrm{C}(\mathrm{XXTV}) / 1957$ dan resolusi 2076/1977, sebagian besar juga diatur dalam instrumen-instrumen nasional.

- Hak-hak korban salah pemidanaan dan korban penganiayaan yang dilakukan oleh pejabat yang berwenang, hal mana secara jelas dan detail diatur dalam instrumeninstrumen internasional tidak diatur dengan jelas dalam instrumen nasional, kecuali dalam Konvensi Ada perbedaan yang cukup signifikan antara aneka penghukuman terhadap narapidana yang melakukan berbagai pelanggaran disiplin lembaga (melakukan pelanggaran atas aturan dan tata tertib lembaga penahanan/penjara). Dalam instrumen nasional, terdapat hukuman tutupan sunyi maupun hukuman untuk menghentikan atau menunda hak tertentu untuk jangka waktu tertentu bagi narapidana yang dianggap melakukan pelanggaran hukuman disiplin. Padahal dalam instrumeninstrumen internasional, bentuk 
hukuman yang demikian ini dilarang.

Mengenai kelengkapan keamanan yang standar bagi petugas lembaga penahanan atau pemenjaraan dalam menjalankan tugas kesehariannya, perlu sangat selektif dalam penggunaan senjata api. Dalam instrumen nasional, penggunaan senjata api justru dinyatakan secara eksplisit sebagai satu kondisi yang umum/biasa.

Dalam kegiatan pengenalan lingkungan bagi narapidana yang baru masuk ke lembaga pemenjaraan, yang pada saat itu diberikan pengenalan fisik lingkungan, juga seyogyanya diberikan pengenalan atas peraturanperaturan yang eksis dalam lembaga, tentang apa yang boleh dan tidak boleh dilakukan oleh narapidana, juga tentang hak dan kewajiban narapidana. Bila dalam instrumen internasional, informasi-informasi tersebut wajib diberikan oleh pejabat lembaga pemenjaraan, tetapi dalam instrumen nasional pemberian pengenalan lingkungan ini diberikan oleh kepala blok. Kepala blok adalah narapidana, yang biasanya dipilih atas kualifikasi pendeknya sisa masa hukuman dan perilaku patuh "hukum" (sesungguhnya hanya patuh kepada petugas) serta memiliki kewibawaan atas narapidana lain, pihak yang diberikan tanggung jawab oleh petugas yang berwenang dalam lembaga sebagai penyambung lidah petugas, dan menjadi penanggung jawab atas ketertiban dan keamanan di wilayah bloknya yang terdiri atas beberapa kamar dan dihuni oleh sejumlah narapidana.

Dalam instrumen internasional, secara jelas diatur tentang keberadaan lembaga pengawas yang independen (ombudsman atau oversight committee) atas bekerjanya lembaga-lembaga dan administrasi pemenjaraan, untuk memastikan bahwa lembaga-lembaga ini telah bekerja sebagaimana aturan dan perundang-undangan yang berlaku. Lembaga yang independen ini juga memiliki otoritas atas akses yang luas ke dalam lembaga pemenjaraan dan terhadap narapidana. Narapidana pun memiliki hak untuk menyampaikan keluhan kepada lembaga. Pengawas yang independen ini secara bebas dan tanpa didengarkan oleh pejabat lembaga pemenjaraan. Tentang lembaga pengawas yang independen ini tidak diatur dalam instrumen nasional.

Prinsip-prinsip dasar bahwa pengaturan lembaga pemenjaraan harus meminimalkan berbagai perbedaan diantara kehidupan dalam lembaga dengan kehidupan bebas, yang bertujuan untuk mengurangi pertanggung jawaban para narapidana karena martabat mereka sebagai insan manusia, juga dianut oleh instrumen nasional. Hal-hal tentang pencatatan identitas diri narapidana, kategori-kategori penempatan narapidana, akomodasi, kebersihan pribadi, pakaian narapidana dan tempat tidur, makanan, pelayanan kesehatan, dan lain-lain, mesldpun tidak diatur secara rinci sebagaimana dalam Standard Minimum Rules (UN), dalam instrumen nasional pun hampir semuanya telah diatur, walaupun memang dengan kualitas yang lebih rendah ketimbang ketentuan yang secara eksplisit disebut dalam Standard Minimum Rules (UN). Misalnya, dalam hal pemberian pakaian, perlengkapan tidur, ketersediaan obat-obatan dan petugas medis demikian pula masalah sanitasi dan ventilasi kamar atau sel narapidana.

Berkaitan dengan restorative justice, maka terdapat banyak sekali hal yang terdapat dalam ketentuan internasional ataupun nasional yang terkait dengan penahanan/pemenjaraan sebagai kegiatan terminal yang harus memiliki kontribusi pada kehidupan 
yang lebih baik, minimal sama, pada diri pelanggar hukum pasca penghukuman. Penekanan pada pemberian pelatihan vokasional sebagai bekal di masa depan, adalah salah satu bentuknya. Dengan kata lain, penghukuman tidak lagi merupakan instrumen retributif ataupun rehabilitatif tetapi juga restoratif. Walaupun demikian, masih berkaitan dengan ide restorative justice, maka terdapat banyak sekali hal yang belum diatur dalam ketentuan internasional ataupun, apalagi, nasional. Pemenuhan hak-hak asasi tahanan dan narapidana memang tidak dapat disingkirkan, namun seyogyanya dilaksanakan bersamaan dan seimbang dengan pemenuhan hak-hak asasi pihak-pihak yang terkait dengan pelaku kejahatan. Tidak hanya itu, sistem pemasyarakatan yang secara konsisten dan optimal menganut pemikiran restorative justice, sebenarnya tidak menuntut diberlakukannya berbagai hal yang selama ini telah diatur dalam ketentuan internasional ataupun nasional mengenai pembinaan ataupun perlakuan terhadap narapidana.

Perspektif restorative justice juga menuntut diadakannya pembentukan ataupun perubahan (bila sebelumnya sudah terbentuk) menyangkut lembaga-lembaga lain di luar lembaga pemasyarakatan guna bersama-sarna lembaga pemasyarakatan merestorasi perilaku jahat atau menyimpang dari narapidana. Baik ketentuan internasional maupun nasional tidak menyinggung hal itu. Ide restorative justice menghendaki agar proporsi lembagalembaga lain tersebut cukup signifikan dibandingkan dengan lembaga pemasyarakatan, melambangkan tersedianya cukup alternatif dalam rangka pemberian sanksi sosial bagi anggota masyarakat yang melakukan kejahatan dan penyimpangan.
Keadaan Di lapangan:

- overpopulation, berimbas kepada banyak persoalan seperti keterbatasan ruang, fasilitas pembinaan, fasilitas-fasiltas dasar seperti tempat tidur, pakaian, dan lain-lain. Ancaman keributan atau kerusuhan dalam lembaga, kontrol dan perhatian petugas yang terbatas akibat perbandingan yang tidak ideal antara jumlah petugas dengan narapidana, akses terhadap kegiatan-kegiatan pembinaan dan keterampilan kerja yang sangat terbatas.

- indikator keberhasilan pembinaan dalam lembaga cenderung dilihat oleh pejabat lembaga melalui sejauh mana kepatuhan narapidana terhadap peraturan lembaga yang direpresentasikan oleh ada tidaknya pelarian dan keributan dalam lembaga dengan demikian maka prioritas utama pembinaan adalah menciptakan kestabilan keamanan dalam lembaga melalui peraturan-peraturan yang ketat, sanksi hukum yang keras (meskipun tidak ada kepastian dan kejelasan). Karena berprioritas pada kestabilan dan keamanan institusi, maka program pembinaan berjalan dengan semangat 'asal ada kegiatan'. Minimnya anggaran juga menyebabkan Lapas sulit mengatur program kegiatan yang benarbenar tepat sasaran. Anggaran terbesar diserap oleh kebutuhan akan makanan bagi napi.

- pelatihan kerja atau keterampilan, seringnya hal itu tidak sesuai dengan karakteristik, minat dan keinginan mereka, atau sudah tidak sesuai lagi dengan kebutuhan dan kondisi di luar lembaga. Ketertinggalan teknologi dan tidak bervariasinya pemberian keterampilan justru menyebabkan kegiatan 
menjadi tidak efektif, dengan biaya produksi yang tinggi dan hasil yang tidak maksimal. maka, tidaklah terlalu mengherankan bila hal tersebut menyebabkan kebanyakan bekas narapidana menemui kesulitan untuk berintegrasi kembali ke dalam masyarakat. Selain, tentu saja, persoalan stigma negatif yang menempel pada 'label' bekas narapidana menyebabkan banyak perusahaan atau majikan tidak mau menerima 'eks napi' sebagai pegawainya.

- program pembinaan dititikberatkan pada kegiatan pembinaan agama karena pejabat yang berwenang memandang kejahatan sebagai dosa, sehingga konsep tentang tobat dan akhlak, masih sangat kental. Menurut mereka, persoalan kejahatan adalah persoalan tidak adanya iman yang kuat dari para pelakunya.

Penempatan narapidana di dalam Lapas juga menimbulkan "korban" baru (secondary but indirect victimisation). Napi sudah berkeluarga, mengharuskan istri dan keluarganya (seperti orangtua, saudara, dan lain-lain) untuk menanggung biaya hidup anakanaknya. Mereka tidak ingin kembali ke tempat tinggal asalnya menggambarkan bahwa tidak ada upaya reintegrasi, baik antara pelaku dengan korban, juga antara pelaku dengan masyarakat, yang mestinya menjadi inisiatif dan dilakukan oleh sistem peradilan. Realitas program pembinaan narapidana di dalam dan di luar lembaga, tidak bisa dipisahkan dari kondisi sumber daya petugas yang secara umum tidak cukup kapabel. Dalam melaksanakan pembinaan Lapas terdapat faktor-faktor yang mendapat perhatian karena dapat berfungsi sebagai faktor pendukung dan lebih lagi yang perlu diperhatikan yakni apabila terdapat sebagai faktor yang menjadi kendala. Munculnya kendala-kendala tersebut tentunya perlu untuk segera dicari pemecahannya agar dalam proses pembinaan terhadap anak didik pemasyarakatan dapat dilaksanakan dengan baik dan lancar. Adapun kendala-kendala tersebut antara lain :

1. Dana

Dana merupakan faktor utama yang menunjang untuk pelaksanaan pembinaan anak didik pemasyarakatan dalam pelaksanaannya maka dibutuhkan peralatan dan bahan-bahan. Sebab program pembinaan tidak hanya 1 (satu) macam saja melainkan banyak macamnya sesuai dengan bidang minat maupun pekerjaan atau keterampilan yang mungkin diperlukan untuk kebutuhan dan kepentingan bagi napi setelah mereka keluar dari Lapas. Kurang atau tidak adanya dana menjadi salah satu faktor penyebab yang menjadi faktor penghambat bagi pelaksanaan pembinaan, karena dapat mengakibatkan tidak berjalan dan tidak terealisasinya semua program pembinaan bagi anak didik pemasyarakatan karena sangat minimnya dana yang tersedia.

2. Petugas

Dalam pembinaan, petugas mempunyai peran yang sangat penting. Hal yang menjadi dasar yang dapat mempengaruhi pola perilaku dan bertindak para petugas tentunya berupa tingkat pengetahuan khususnya yang berkaitan dengan sistem pemasyarakatan itu sendiri. Sehingga petugas dituntut untuk dapat mengerti tentang persoalan-persoalan yang timbul demi lancarnya proses pembinaan tersebut.

3. Narapidana 
Keberhasilan dari terlaksananya program pembinaan terhadap napi tidak hanya tergantung dari faktor petugasnya, melainkan juga dapat berasal dari faktor napi itu sendiri juga memegang peran yang sangat penting. Adapun hambatanhambatan yang berasal dari narapidana antara lain :

a. Tidak adanya minat

b. Tidak adanya bakat

c. Watak diri

4. Sarana dan fasilitas pembinaan

Kurangnya peralatan atau fasilitas baik dalam jumlah dan mutu juga banyaknya peralatan yang rusak menjadi salah satu faktor penghambat untuk kelancaran proses pelaksanaan pembinaan terhadap narapidana, karena dari semuanya itu tidak tertutup kemungkinan faktor tersebut menjadi penyebab tidak aman dan tertibnya keadaan di dalam penjara.

5. Kualitas program pembinaan

Kualitas dan bentuk-bentuk program pembinaan tidak sematamata ditentukan oleh anggaran maupun sarana dan fasilitas yang tersedia. Tetapi diperlukan program-program pembinaan yang kreatif dan murah serta mudah untuk dilakukan, sehingga dapat berdampak sebagai pembelajaran yang optimal bagi napi sebagai bekal keterampilannya untuk kelak setelah keluar dari Lapas.

6. Kesejahteraan petugas

Disadari sepenuhnya bahwa faktor kesejahteraan petugas pemasyarakatan di indonesia memang dibilang masih memprihatinkan, hal ini disebabkan karena keterbatasan dana dan kemampuan untuk memberikan tunjangan bagi petugas pemasyarakatan. Maka imbalan yang diperolehnya menjadi belum seim- bang dibandingkan dengan tenaga yang mereka sumbangkan untuk bekerja siang dan malam tanpa mengenal lelah di dalam Lapas. Namun pada dasarnya faktor kesejahteraan petugas ini jangan sampai menjadi faktor yang menyebabkan lemahnya pembinaan dan keamanan serta ketertiban di dalam Lapas.

7. Masyarakat dan pihak korban

Pada dasarnya masyarakat juga merupakan faktor yang mempengaruhi pelaksanaan pembinaan terhadap napi, karena masyarakat secara tidak langsung menjadi penentu berhasil tidaknya proses pembinaan di Lapas. Dalam hal pembinaan berupa program integrasi, masih terdapat kendalakendala seperti kebanyakan lingkungan masyarakat dan pihak korban tidak mengizinkan kepadanya untuk kembali lagi ke masyarakat meskipun hanya sebentar.

\section{PENUTUP}

Kesimpulan

Lembaga pemasyarakatan merupakan tempat untuk melaksanakan pengayoman serta pemasyarakatan narapidana, akan tetapi disisi lain Lembaga Pemasyarakatan memang tidak bisa memberikan suatu jaminan, bahwa warga binaan yang sudah dibina itu pasti mau mentaati peraturan dan tidak melakukan kejahatan lagi, serta juga tidak ada jaminan bahwa program yang dilaksanakan dalam rangka pengayoman serta pemasyarakatan warga binaan pasti membawa hasil yang memuaskan.

Pembinaan yang diberikan kepada narapidana yang berorientasi pada masa depan yang cerah dapat diwujudkan, apabila narapidana itu secara 
sungguh-sungguh menyadari bahwa pidana penjara yang dijatuhkan kepada mereka bukanlah dimaksudkan untuk membalas perbuatan yang dilakukan oleh warga binaan itu, akan tetapi untuk mengayomi serta memasyarakatkan napi itu kejalan yang benar agar mereka menjadi manusia yang baik dan bertanggung jawab sesuai dengan harkat dan martabatnya.

Lembaga Pemasyarakatan mempunyai tugas untuk memulihkan terbentuknya kesatuan hubungan hidup kehidupan dan penghidupan narapidana sebagai Individu, anggota masyarakat dan Makhluk Tuhan YME, selain itu juga untuk melaksanakan perawatan tahanan, pembinaan dan pembimbingan narapidana dalam kerangka penegakan hukum, pencegahan dan penaggulangan kejahatan serta pemajuan dan perlindungan HAM.

Saran

1. Perlunya pengiriman pegawai untuk mengikuti program kekhususan yang dilaksanakan instansi lain yang berkaitan dengan kegiatan keterampilan.

2. Perlunya kerjasama dengan instansi lain untuk memasarkan hasil produk napi di Lapas, apabila ada produk yang dihasilkan.

3. Program dan ragam pembinaan terhadap narapidana hendaknya dilaksanakan secara efektif dan kreatif serta berdaya guna untuk pengembangan kepribadian serta peningkatan keterampilan bagi narapidana.

4. Kesejahteraan petugas pada umumnya dan petugas pemasyarakatan pada khususnya hendaknya lebih diperhatikan dan ditingkat- kan kesejahteraannya oleh Pemerintah, mengingat pengabdian yang mereka berikan untuk kepentingan bangsa dan negara bukna untuk kepentingan mereka sendiri.

\section{DAFTAR PUSTAKA}

Arswendo Atmowiloto, Hak-Hak Narapidana, Elsam, Jakarta, 1996

Harsono HS, Sistem Baru Pembinaan Narapidana, Djambatan, Jakarta, 1995.

Lamintang P.A.F., Drs.SH., Hukum Penitensier Indonesia, Armico, Bandung, 1984.

Nur Rochaeti, SH. MHum, Pembinaan narapidana di LP Kedung Pane Semarang, Majalah Hukum Undip, Semarang, 2004.

Nur Rochaeti, SH. Mhum, Sejarah Perkembangan Penjara: Dari Bui Ke Pemasyarakatan, Bahan Kuliah Penologi, Penologi Suatu Pengantar

Sudarto, SH, Hukum Pidana 1, Yayasan Sudarto : FH Undip, Semarang, 1991

Suatu Laporan dari ASIA WATCH, Kondisi-Kondisi Penjara Di Indonesia, 1990 www.nicic. org. Keadilan Restoratif, diambil dari Tony Marshall, yang dikutip dalam Restorative Justice Of Printiciple. Kelompok Kerja PBB 